\title{
EXPERIENCE THE FUTURE OF LEGAL EDUCATION
}

\author{
LORNE SOSSIN ${ }^{*}$
}

This article examines the shift towards experiential legal education and its implications. While others have focused on experiential education as a means of training better lawyers, the author advances the argument for experiential education because it is rooted in substantive problem-solving, access to justice, engagement with communities, and greater opportunities for reflective and critical thinking about law and justice. Drawing on examples from Osgoode Hall Law School, which adopted an experiential curricular requirement in 2012, the article explores the ways in which experiential education may change law school and law students. The article also canvasses the implications of the experiential shift for the future of legal education, and the blurring lines between law school and transitional professional education in law such as articling and Practical/Professional Legal Training Courses (PLTCs). Finally, a number of perspectives and research initiatives are presented to suggest that the benefits of an effectively designed experiential model are far reaching, from a learning environment that caters most effectively to the way in which students learn and access information, to increasing engagement with community needs, to the positive impacts on student wellness. Therefore, the article illustrates the significance of the experiential shift in legal education in the Canadian context as a critical driver in the evolution of the law school and professional legal education.
Cet article porte sur le virage de la formation juridique par expérience et ses implications. Alors que d'autres ont ciblé l'éducation expérientielle comme moyen de former de meilleurs avocats, l'auteur fait valoir le bien-fondé de cet apprentissage parce qu'il est ancré dans la résolution de problèmes de fond, l'accès à la justice, la mobilisation communautaire et de meilleures possibilités de réflexion et de pensée critique sur le droit et la justice. L'article s'inspire d'exemples de l'école de droit Osgoode Hall qui a adopté l'exigence du programme expérientiel en 2012 pour explorer comment l'éducation expérientielle peut changer une école de droit et ses étudiants. L'article examine aussi à fond les implications du virage expérientiel pour l'avenir de la formation juridique ainsi que les lignes floues entre l'école de droit et la formation professionnelle transitoire en droit comme les stages et les cours de formation juridique pratiques et professionnels. Enfin, plusieurs points de vue et initiatives de recherche sont présentés laissant entendre que les avantages profonds d'un modèle expérientiel bien conçu allant d'un environnement d'apprentissage plus réceptif à la manière dont les étudiants apprennent et accèdent à l'information, à un meilleur engagement à l'égard des besoins communautaires et un impact positif sur le bien-être des étudiants. En conséquence, l'article illustre l'importance du virage expérientiel de la formation juridique dans le contexte canadien comme un moteur critique de l'évolution des écoles de droit et de l'éducation juridique professionnelle.

\section{TABLE OF CONTENTS}

I. INTRODUCTION . . . . . . . . . . . . . . . . . . . . . . . . 850

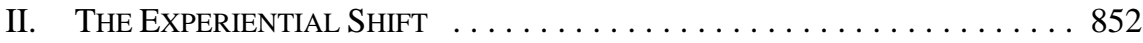

III. BEYOND "LEARNING BY DOING”

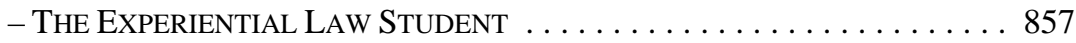

IV. EXPERIENCING THE FUTURE OF LEGAL EdUCATION . . . . . . . . . . 862

A. The Law School Firm $\ldots \ldots \ldots \ldots \ldots$

Dean, Osgoode Hall Law School. This article has been prepared for The Future of Law School Conference at the University of Alberta, September 2013, and remains a work-in-progress. It draws on materials and discussion from the University of Saskatchewan Future of Law Conference held in November of 2012. I am also very grateful to the many colleagues at Osgoode Hall Law School who have commented on an earlier draft of this article and more generally have come to shape my appreciation for experiential education. Finally, I am indebted to Senka Grahovac (JD 2015) for her superb research assistance. 


\section{B. Practical/PROFESSIONAL LEGAL \\ TrAining COURSES . . . . . . . . . . . . . . . . . . . . . . . . . . 864 \\ V. CONCLUSIONS ............................. 868}

\section{INTRODUCTION}

Legal education is becoming more experiential, which is a good thing. This essay examines both of these claims, examines the origins of the experiential turn in legal education, and analyzes its implications. This account is written from a Canadian perspective, and more parochially, from an Osgoode Hall Law School perspective. That said, I believe this account is relevant to legal education more broadly, and contributes to the ongoing and vital debate over the future of law school.

Experiential legal education is on the rise. There is little empirical evidence, however, examining the extent of this rise in Canada. From the perspective of Osgoode Hall Law School, though, this trend is both tangible and dramatic. Osgoode accepts approximately 285 students into each entering class. In 2011-12, prior to instituting the “praxicum” requirement, discussed below, Osgoode had approximately 268 spots in classes, intensive programs, and clinical programs that would satisfy this experiential curricular element. In 2013-14, the first year in which the new requirement was in effect for upper-year students, Osgoode had close to 500 available spots. A similar trajectory accompanied Osgoode’s deepening commitment to public interest placements, which is now a universal graduation requirement for all J.D. students. ${ }^{1}$ While not every school has doubled its experiential offerings in the span of a couple years, or has a public interest requirement, I am aware of no school where experiential programs are decreasing. The variation among law schools in the context of this experiential shift is simply with respect to how much, how fast, and through what programs, courses, and initiatives.

Why is legal education becoming more experiential? In some cases, this experiential shift has been driven by a philosophical belief that law schools should do a better job of "educating lawyers" as elaborated, for example, in the oft-referenced 2007 Carnegie Foundation report, Educating Lawyers, ${ }^{2}$ and Best Practices for Legal Education, the even more detailed 2007 study by Roy Stuckey and others on the optimal law school curriculum and pedagogy. ${ }^{3}$ A related rationale is simply that increasing clinical and experiential opportunities in law school is a response to the market and the increasing competition over top students (as well as the competition for support and reputational prestige from law firms). Students who have or are perceived to have "real world" skills are more likely to do better in securing articling or entry-level positions, ${ }^{4}$ and firms and donors will therefore be more The Osgoode Public Interest Requirement is discussed further below. It is worth noting, however, that
a number of praxicum requirements featuring public interest or community work also may satisfy the Public Interest Requirement.

2 William M Sullivan et al, Educating Lawyers: Preparation for the Profession of Law (San Francisco: Jossey-Bass, 2007) [Educating Lawyers].

3 Roy Stuckey et al, Best Practices for Legal Education: A Vision and a Road Map, 1st ed (Clinical Legal Education Association, 2007), online: Clinical Legal Education Association <http://www.clea web.org/Resources/Documents/best_practices-full.pdf> [Best Practices for Legal Education].

NALP \& The NALP Foundation, 2010 Survey of Law School Experiential Learning Opportunities and Benefits (2011), online: NALP <http://www.nalp.org/uploads/2010ExperientialLearningStudy.pdf> [2010 Survey of Experiential Learning]. 
inclined to want to be associated with programs that are coveted by students and which generate a positive profile. In other words, law schools will tend to become more experiential because students and employers want them to. Finally, the new accreditation process introduced by the Federation of Law Societies of Canada and confirmed by each of the provincial law societies, has put a premium on experiential education through the new nationally required competencies. ${ }^{5}$ The competencies approach moves off the framework of specific required courses and allows or encourages law schools to address the required competencies through more innovative programs of study. Further, some of the competencies, such as problem-solving skills, lend themselves to being addressed through experiential contexts. While these rationales may go some ways to explaining why legal education is becoming more experiential, they do not account for why this is a good thing.

In my view, the experiential shift is a good thing for the future of legal education because it represents a more effective, rigorous, and intellectually engaging means of teaching and learning law. In other words, the experiential shift should be welcomed (and advanced) because it enriches academic values in legal education and legal scholarship.

In this brief article, I discuss why I believe this to be so, and the implications for the broader vision of law schools to which this experiential shift gives rise. In short, I argue that experiential learning transforms legal education from a focus on conveying specialized knowledge about law (and, in its best incarnations, critical analysis of law) to a problemsolving model, in which the goal of law school curriculum is deploying legal knowledge (and, ideally, critical analysis) in order to advance our understanding of law and its contexts, and in order to improve the justice system and society.

Importantly, this experiential shift is taking place in the midst of a digital transformation in the post-secondary sphere (and virtually every other sphere of social and economic life). We are fast reaching the point when the overwhelming majority of technical and specialized knowledge in law, and much critical analysis as well, is available to all, for free, online (in varying degrees of quality and accessibility). Therefore, if all law schools do is provide a space for faculty to disseminate information and opinion from their hard drive to the hard drive of their students' laptops, law schools will quickly find themselves no longer relevant. Problem-solving, however, is inherently experiential. It requires adapting ideas, principles, and approaches to shifting and complex life circumstances and seeing, in turn, how ideas, principles and approaches themselves shift and become more complex as a result. In other words, experiential education not only is a better way to learn law, it also represents a critical driver in the evolution of the law school and of professional legal education. A problemsolving curriculum should not be juxtaposed to digital legal education - in many ways, digital platforms are the optimal means for enriching experiential legal education. Such a curriculum, however, cannot be downloaded or received passively. It must be experienced and interactive to be of value. That is its defining characteristic.

Task Force on the Canadian Common Law Degree, Final Report, October 2009 (Federation of Law Societies of Canada, 2009), online: The Federation of Law Societies of Canada <http://www.flsc.ca/ _documents/Common-Law-Degree-Report-C.pdf $>$ at 4. 
This analysis is divided into three parts. In the first part, I examine the experiential shift in legal education and why I believe this enhances the quality, breadth, and depth of legal education. In the second part, I explore ancillary shifts in legal education that flow from an experiential model. These range from more significant collaboration, engagement with external parties and communities, and initiatives that also address community needs and access to justice. Finally, in the third part, I canvass the implications of the experiential shift for the future of legal education, and particularly the blurring lines between law school and transitional professional education in law such as articling and Practical/Professional Legal Training Courses (PLTCs). This analysis is not intended as either a comprehensive or scientific study. It is impressionistic, partial, and draws, in particular, on my experience with the deepening commitment to experiential legal education at Osgoode Hall Law School. ${ }^{6}$ That said, I hope it makes a contribution to the broader discussion on the future of legal education.

\section{THE EXPERIENTIAL SHIFT}

Experiential education in law is certainly not a new idea and can mean different things to different observers. Some see it simply as practical or "work” experience in law. Some see it as clinical work, involving the provision of legal services to clients. Still others see it as a way of enlivening material in the classroom by use of simulations and group work. Some might date its origins in Canada to the founding of the first community legal clinics (such as the establishment of Parkdale Community Legal Services in 1971), ${ }^{7}$ while others may trace it back to the days when lectures were joined with apprenticeship at law schools run by provincial law societies, as in the early years of Osgoode Hall Law School. I am not aware of any purely experiential program in legal education, nor would such a program likely be successful. Experiential education works best when integrated with other forms of learning so that theory, doctrine, practice, and critique all become seamlessly enmeshed in the law school experience.

While I believe the experiential shift will (and should) reshape law schools, it is important at the outset to clarify what I take experiential education in law to encompass for purposes of this analysis. The core of that approach is captured by what Osgoode Hall Law School has termed the praxicum requirement (a curricular requirement adopted in 2011, which has come into effect for the students who entered the J.D. program in 2012). There are three components, which must be in place for a course or program to fit within an experiential "praxicum" rubric. First, the course or program must include exposure to the relevant law and context for the field. Even where a program features students spending time on externships or external placements, those students also need to engage with the relevant ideas in the field. A legal co-op program, for example, may be desirable from the standpoint of skills training, but could not in and of itself constitute a praxicum. Second, the course or program must include a substantial component in which the student is actively engaged in problem-solving, whether in actual client contexts, simulated exercises or institutional

$6 \quad$ This commitment is set out in many places at Osgoode but captured institutionally in the Law School's 2011-2016 Strategic Plan: “Experience Osgoode: Strategic Plan 2011-2016,” online: Osgoode Hall Law School <http://digital.yorku.ca/i/59910> at 2.

“The Clinic,” online: Parkdale Community Legal Services <http://www.parkdalelegal.org/index.php? option=com_content\&view=article\&id=56\&ltemid=34>. 
settings. Third, and perhaps most importantly, there must be an opportunity for students to reflect on the problem-solving experience, to connect the dots, as it were, between the substantive exposure to legal ideas and the hands-on exposure to law in action. ${ }^{8}$

This tripartite approach to experiential education flows from several core principles. The first principle is that there is no tenable juxtaposition between the research-based and practical learning in law. Experiential learning must incorporate both. In other words, this is not a step back to a time of "trade school” legal education by apprenticeship; rather, it is a model that seeks the fusion of theory and practice. ${ }^{9}$ Indeed, it is no coincidence that the introduction of the praxicum requirement at Osgoode was accompanied by a new adaptive research and writing requirement, as the two curricular commitments stem from a shared source.

I had an opportunity to apply this conceptual approach in the context of two experiential directed research courses over the past two years. In 2011-12, I led a course on "JAG Perspectives on Administrative Law, Military Justice and International Operational Law."10 The course involved a group of Osgoode students engaged in collaborative research with the Judge Advocate General (which has a branch office on the Canadian Forces Downsview base close to Osgoode). ${ }^{11}$ The JAG lawyers developed a list of topics where the interpretation or application of domestic or international legal standards was uncertain, and I co-supervised each student's research (with assistance from a range of Osgoode faculty with subject area expertise on the particular topic) while each student also had a JAG lawyer as co-supervisor. Students came together several times both at Osgoode and the Downsview base to present outlines, discuss research approaches, and ensure the resulting paper was both responsive to the problem and context of the JAG office and responsive to the academic standards of the Law School.

In 2012-13, I co-supervised a similarly structured directed research course on "Mental Health Law and Justice” involving a collaboration with the Centre for Addiction and Mental Health (CAMH) and Nyranne Martin, in-house counsel at CAMH. ${ }^{12}$ Again, CAMH lawyers developed the topics and Osgoode students explored how best to provide responsive research that was also relevant. For example, one student's research might result in a paper while another student's project could culminate in draft guidelines or material aimed at a submission to a legislative committee on a topic of law reform.

For discussion of the praxicum requirement, see Curriculum Reform Working Group, Report on the Reform of the Upper Year JD Curriculum (Osgoode, December 2010) at 22-27 [unpublished, on file with author].

9 For an excellent discussion of this era at Osgoode Hall Law School, roughly from 1889 to the mid1950s, see C Ian Kyer \& Jerome E Bickenbach, The Fiercest Debate: Cecil A Wright, the Benchers, and Legal Education in Ontario 1923-1957 (Toronto: University of Toronto Press, 1987).

10 I discussed my experience with this course in a blog post: Lorne Sossin, "JAG Perspectives on Administrative Law, Military Justice and International Operational Law” Dean Sossin's Blog (2 June 2012), online: Osgoode Hall Law School < http://deansblog.osgoode.yorku.ca/2012/06/jag-perspectiveson-administrative-law-military-justice-and-international-operational-law/>.

11 See "Judge Advocate General (JAG)," online: National Defence and the Canadian Armed Forces $<$ http://www.forces.gc.ca/en/about-org-structure/judge-advocate-general.page>.

12 For reflections on the experience by students and supervisors, see "Osgoode-CAMH Collaborative Research Course in Mental Health \& Justice,” online: Osgoode Hall Law School < http://www.osgoode. yorku.ca/node/24014>. 
Through the JAG and CAMH courses (in addition to other kindred research collaborations with partner organizations at Osgoode and through the University of Toronto's Capstone Program developed during my years on faculty there), I have seen the transformative effect on students when research and scholarship are paired with problem-solving and relevance to a real-time issue or dilemma.

My anecdotal impressions aside, empirical data on legal education appear to back up the claim that experiential education on a praxicum model may have demonstrated benefits over alternative approaches. In “Training Tomorrow’s Lawyers: What Empirical Research Can Tell Us About The Effect of Law School Pedagogy on Law Student Learning Styles,” the authors draw on a variety of studies to conclude that the ideal learning process involves:

(1) an experience that exposes the learner to a new concept or new information ...; (2) subsequent reflection upon, or review of, that experience in order to better understand it ...; (3) drawing conclusions about the experience and properly cataloging it along with prior knowledge or experiences ...; and (4) doing something with the experience, such as ... applying what was learned in a problem-solving context. ${ }^{13}$

Beyond the praxicum setting, experiential education also encompasses programs that may not lead to academic credit. For example, Osgoode Hall Law School and the University of Toronto collaborate with the Law in Action Within Schools organization (LAWS), which works to develop and deliver justice education and mentoring to youth at risk in several Toronto high schools. Pro Bono Students Canada places law students throughout Canada in a variety of law related placements focused on subjects ranging from human rights to corporate law reform. At Osgoode, these public interest roles have been incorporated into an experiential program known as the Osgoode Public Interest Requirement (OPIR). ${ }^{14}$ OPIR constitutes a graduation requirement, so in this sense is not "extracurricular" and to fulfill this requirement students may take certain designated for-credit courses, or go on a noncredit, approved placement. To meet the requirement, students must engage in at least 40 hours of law related public interest activity, combined with a reflective component (either a short paper or participation in a discussion group). There are, of course, many other models of this form of experiential learning: some mandatory, some voluntary, and some with other kinds of incentives to participate.

Thus, while any attempt to define the scope of experiential education is daunting, I would suggest three elements must always be present: (1) exposure to substantive or procedural legal knowledge; (2) engagement in law related activity; and (3) the opportunity to reflect on legal experience and its implications for legal ideas.

Experiential education suggests not just a different curricular requirement but also a shift in pedagogy and the assessment of law students. Rather than focusing primarily on outcomes in the evaluation of law students (for example, correct answers on an exam), the focus of experiential assessment aspires to achieve a balance between process and outcome - how successfully did a student solve the problem at hand and how well did the student engage in

$13 \quad$ Eric A DeGroff, “Training Tomorrow’s Lawyers: What Empirical Research Can Tell Us About The Effect of Law School Pedagogy on Law Student Learning Styles” (2012) 36:2 S Ill ULJ 251 at 265.

14 “Osgoode Public Interest Requirement," online: Osgoode Hall Law School < http://www.osgoode.yorku. ca/opir>. 
the problem-solving process? ${ }^{15}$ Self-assessment and peer-assessment also become important aspects of evaluation when the goal is not just to demonstrate knowledge or the ability to engage in analysis but to show reflective capacities such as self-awareness or ethical judgment.

The second principle is that experiential education does not privilege one subject area of law over another - it is not, in other words, better suited to poverty law than corporate law, nor is labour a more challenging context in which to design a valuable experiential program than intellectual property or immigration law. Indeed, it is difficult to imagine an area of law that is not susceptible to experiential learning. Core doctrinal instruction in public and private law all can (and should) be conceptualized as a problem-solving process that can take place both inside and outside the classroom. Jessica Erickson makes the case for experiential education in doctrinal cases as more consistent with cognitive research on effecting learning. ${ }^{16}$ That said, whether experiential education in law begins on the first day of law school or builds on foundational courses, it has become an important window into how experiential models enable (and sometimes compel) law schools to rethink other aspects of legal education.

The experiential shift, for example, has led some observers to reconceptualize the optimal sequence of the law school curriculum. ${ }^{17}$ The Best Practices for Legal Education report, for example, suggests a first-year program should be organized around the analysis of law, a second-year program should be organized around the analysis of facts and problem-solving while a third-year program should be organized around the "practical wisdom" through experience. ${ }^{18}$ Further to this model, some law schools in the United States have experimented with a capstone of a third year devoted entirely to experiential learning. In "Practice Ready: Are We There Yet?,” Margaret Barry proposes a model law school curriculum that would best prepare students for the legal profession. ${ }^{19}$ She observes that while some law schools have diversified their first-year curriculum by adding electives and practice-oriented courses, and most offer experiential offerings in second and third years, there has been little reflection on how these pieces fit together and relate to the overall educational enterprise. Her recommendations include: (1) maintaining basic doctrinal courses but infusing them with factual context, problem-solving, ethics, and professionalism; (2) more active techniques in second year, such as simulations and role play to teach additional skills - even in large classes; and (3) devoting the third year to experiential education, thereby allowing students to deploy skills and knowledge acquired, while working with real cases.

Washington and Lee University School of Law attracted significant attention in 2009 when it revamped its third-year program. The third year consists of four components that

15 Stefan H Krieger \& Serge A Martinez, “Performance Isn’t Everything: The Importance of Conceptual Competence in Outcome Assessment of Experiential Learning” (2012) 19:1 Clinical L Rev 251. Jessica Erickson, “Experiential Education in the Lecture Hall” (2013) 6:1 Northeastern University Law Journal 87 at 90-91, 95-96.

See Deborah Maranville et al, "Re-vision Quest: A Law School Guide to Designing Experiential Courses Involving Real Lawyering” (2012) 56:2 NYL Sch L Rev 517 at 540.

Supra note 3 at 205-209.

Margaret Martin Barry, “Practice Ready: Are We There Yet?” (2012) 32:2 Boston College Journal of Law \& Social Justice 247 at 267-73. 
blend the practical and the intellectual into a diverse range of simulated and real practiceoriented experiences:

- A two week long skills immersion at the beginning of each semester, one focusing on litigation and conflict resolution, the other on transactional practice

- $\quad$ Four elective courses, one real-client experience (either a clinic, an externship or a Transnational Human Rights program) and three additional electives taught in a problems-based, practicum style

- At least forty hours of law-related service

- $\quad$ Participation in a semester-long professionalism program. ${ }^{20}$

Some law schools, such as Stanford University, have focused their curricular reform on increasing the cross-disciplinary offerings and emphasizing problem-solving within the curriculum (by revamping joint-degree programs, increasing international opportunities, and developing team-oriented, problem-solving courses co-taught by law school and other school faculty). ${ }^{21}$ Many have focused their reforms on the third year of law school. University of California Hastings College, for example, developed the Lawyers for America program, where students work full-time for the public defenders office (with the understanding that they will be hired back the following year for a salary). ${ }^{22}$ As a two-year fellowship program, it encompasses the final year of law school and the first year as an attorney. ${ }^{23}$

While the experiential shift has been widespread both in the US and Canada, experiential education has of course spawned critics as well. ${ }^{24}$ The critics tend to focus on one of two objections with experiential education. The first is that it represents a regression from academic autonomy from the profession and conflates legal education with training lawyers, or, relatedly, that it demonstrates the capture of legal education by markets and those who do their bidding. ${ }^{25}$ These concerns are both well-founded and far-reaching, but not selfevident. In other words, while experiential education can degenerate into a practitioneroriented series of "how-to" courses, or reflect the needs of markets more than the public interest, it need not do so. Further, I would suggest, experiential education has the potential to promote critical thinking about law and the impact of markets more effectively than its classroom doctrinal or theoretical counterparts.

“Washington and Lee’s New Third Year Reform,” online: Washington and Lee University School of Law <http://law.wlu.edu/thirdyear/>.

Mary Anne Toman-Miller, "Law School Pioneers New Curriculum” The Stanford Daily (21 February 2012), online: The Stanford Daily <http://www.stanforddaily.com/2012/02/21/law-school-reformscurriculum>.

"About Lawyers for America," online: University of California Hastings College of the Law <http:// www.uchastings.edu/academics/clinical-programs/lawyers-for-america/index.php>.

See also Carrie Hempel, "Writing on a Blank Slate: Creating a Blueprint for Experiential Learning at the University of California, Irvine School of Law” (2011) 1:1 UC Irvine Law Review 146.

See e.g. Gary Shaw, "A Heretical View of Teaching: A Contrarian Looks at Teaching, the Carnegie Report, and Best Practices” (2012) 28:4 Touro L Rev 1239.

See the prodigious examinations and critiques of legal education from Harry Arthurs: Consultative Group on Research and Education in Law, Law and Learning: Report to the Social Sciences and Humanities Research Council of Canada (Ottawa: The Social Sciences and Humanities Research Council, 1983) [Arthur Report]; Harry W Arthurs, "Poor Canadian Legal Education: So Near to Wall Street, So Far From God” (2000) 38:3 Osgoode Hall LJ 381; Harry W Arthurs, “The State We're In: Legal Education in Canada’s New Political Economy” (2001) 20 Windsor YB Access Just 35. 
The second objection is that it misconstrues the mischief that afflicts non-experiential legal education; rather than a flawed curriculum, critics point out that the key issue is the quality of teaching. ${ }^{26}$ I think this concern has merit. Experiential education is not a priori superior to doctrinal, case-based classroom education. In other words, a well-taught doctrinal course is going to be significantly more effective than a poorly designed or poorly run experiential program. The Best Practices for Legal Education report itemizes in significant detail the various components of successful teaching in both experiential and nonexperiential settings. ${ }^{27}$ A successful program arguably needs elements of both approaches to legal education which live up to these high standards. That said, the premise of the experiential shift is that the very best doctrinal, case-based classroom experience is likely to pale in comparison to a well-designed and well-executed experiential program.

Still other critical observers point out that experiential education may call into question the existing financial model of law schools; for example, should a law student pay the same tuition during a year of taking classes from full-time faculty as a year of "experiential" placement with a law office or legal clinic in the community? Again, this concern should give rise to vigilance rather than cynicism. In most contexts, experiential education requires greater resources and involves closer faculty supervision than its alternatives. For example, at Osgoode, most clinical and intensive programs involve no more than 12 students at any one time, with both faculty and practitioner involvement. Osgoode established an Office of Experiential Education in 2012 to ensure greater capacity to develop and deliver high-quality experiential programs but also to enhance the consistency of policies, practices, and the student experience across disparate program areas. Without sufficient investment, experiential education can spiral into a "race to the bottom" with downward pressure to spend less, deliver less, and ask less of all those involved.

While not every experiential program is to be lauded, and while there may well be risks in the experiential shift, both the momentum towards more experiential models in legal education, and the transformative implications to which this program is giving rise are apparent. While I have focused thus far on the impact of experiential education on law schools, this shift is also having dramatic effects on the student experience, as discussed in the following section.

\section{BEYOND “LEARNING BY DOING” — THE EXPERIENTIAL LAW STUDENT}

The experiential shift in legal education has been amplified by, and in turn has amplified, the increasing focus on law school courses highlighting teamwork, collaboration, and greater partnership with the legal profession in the delivery of law school courses. I suggest the evolution of the law school curriculum is leading to the evolution of the law student.

Experiential learning puts a premium on law school as an active rather than passive experience. In many schools, the curricular shift mirrors the rise of pro bono and public 
interest opportunities for students, and the proliferation of new student clubs and projects, as well as student-led conferences such as the Student Public Interest Network Legal Action Workshop (SPINLAW), ${ }^{28}$ and programs like OPIR, discussed above. ${ }^{29}$ The focus on experiential education has also lent new focus and in some cases new resources for clinical legal education. It is no coincidence that the Canadian clinical programs came together in 2010 to form the Association for Canadian Clinical Legal Education (ACCLE). ${ }^{30}$

In a 2011 article in Lexpert entitled, "Learning from Doing," the author canvassed various legal leaders for their thoughs on experiential learning. University of Western Ontario Dean Iain Scott highlights the importance of law students learning project management skills, and better blending financial acumen and global exposure into the law school curriculum. ${ }^{31}$ Other commentators have pointed to the growing prominence of "reflective lawyering" skills in the law school experience. Michelle Leering, for example, has advocated the growing use and effectiveness of "learning journals" where students document and explore the learning experience while in the midst of a course or clinical program. ${ }^{32}$

Heather Gardiner, writing in Canadian Lawyer Magazine, links the focus on learning by doing at Canadian law schools to the articling crisis. ${ }^{33}$ She quotes Governor General (and former Law School Dean) David Johnston who similarly highlights the need for law school to demonstrate a greater commitment to "apprenticeships”. His remarks were made at a Canadian Bar Association conference, where he observed:

In my judgment, we have allowed too great a divide to develop between academia and the profession. We do not cure this by forcing the profession back in, but rather by making the compelling case that the three years at law school mark the beginning of the journey of preparing professionals with all three apprenticeships. We should not leave the practical and the ethical apprenticeships to the end — articling and the bar admission course. We should start with how we choose an entering class.... Beginning in law schools, we need to integrate these three apprenticeships — the cognitive, the practical, the ethical-social — as one mutually reinforcing continuum....

As to curriculum in law, I would integrate the bar admission course with the LL.B., similar to what medicine does.... I would also intersperse internships or articling throughout the academic years. I would pair academic and practising lawyers as much as possible in the curriculum, in order to integrate the three apprenticeships. $^{34}$

“About SPINLAW,” online: SPINLAW <http://www.spinlaw.ca>. Supra note 14.

"About," online: Association for Canadian Clinical Legal Education <http://accle.ca/about/>. Doug Ferguson, one of the founders of the ACCLE has also been one of the strongest proponents for experiential education in law more generally.

Sandra Rubin, “Learning from Doing” Lexpert (September 2011), online: Lexpert < http://www.lexpert. ca/magazine/article/learning-from-doing-2020/>; see also Jennifer Champion, "Bringing the Law to Life: Experiential Learning at UVic Law,” University of Victoria Law News (Spring 2008) 10.

Michele Leering et al, "Developing a Disciplined Approach to Reflection: Encouraging Reflective Practice, Integrated Learning, and Sharing Promising Practices - Part I” (Delivered at the 6th Global Alliance for Justice Education Worldwide Conference, Valencia, Spain, 11 July 2011), [unpublished]. Heather Gardiner, "Learning by doing," Canadian Lawyer Magazine (27 February 2012), online: Canadian Lawyer Magazine <http://canadianlawyermag.com/4059/learning-by-doing.html>.

His Excellency the Right Honourable David Johnston, "The Legal Profession in a Smart and Caring Nation: A Vision for 2017” (Speech delivered at the Canadian Bar Association's Canadian Legal Conference, Halifax, 14 August 2011), online: The Governor General of Canada <http://www.gg.ca/ document.aspx?id=14195>. 
In light of the Carnegie Foundation's findings in Educating Lawyers, which emphasized the need for legal education with a greater focus on the practice experience of lawyers and the development of moral and reflective judgment, numerous studies have been undertaken to test and develop these approaches and to assess the effectiveness of the experiential model of legal education. The results of these studies suggest that the dynamic and complex nature of the current legal environment demands a learning model centered on active problemsolving, and requires the integration of academic legal analysis and professional skills and values. ${ }^{35}$ Experiential opportunities focused on providing active exposure and engagement in problem-solving, as well as the opportunity for critical reflection, result in a sustainable model of legal learning and skills acquisition. A recent article assessing the empirical research on student learning styles and law school pedagogy suggests that a vast majority of law school students are, "more likely to be visual learners and holistic, right-brained thinkers rather than sequential, logical thinkers." 36

The experiential education model is effective, in other words, because an active problembased learning environment best fits the way in which students learn and access information. ${ }^{37}$ While the empirical data of this study were not conclusive, other studies point to a cluster of benefits flowing from experiential learning. In particular, the NALP 2010 Survey of Experiential Learning documented the study of associates in private law firms and whether their experiential opportunities in law school affected their development and preparedness as a lawyer. The key findings indicated that experiential opportunities were the most effective preparation for practice. ${ }^{38}$ Other preliminary empirical research suggests that experiential learning through “well-structured critical analysis of real or simulated lawyers' work" 39 also plays a significant role in developing the learning capacity and emotional health of law students.

Not only is an experiential learning model tailored to the diverse legal environment and learning styles of the current and future generations of students, but it also instills a sense of professional responsibility. In particular, experiential education, through transformative learning, allows students to challenge the status quo. ${ }^{40}$ It allows students to discover the "justice issues" in complex problems through experience and critical reflection. ${ }^{41}$ As a result, it has been suggested that critical analytic abilities are also enhanced by experiential models of legal education.

For many, the shift to an experiential approach to legal education is tied not just to problem-solving for its own sake, but to problem-solving as a way to harness law in order to improve society — whether by making markets more efficient, regulations more transparent, or rights better protected.

\section{Journal of Law and Social Justice 215 at 221-22.}

Sharon L Beckman \& Paul R Tremblay, "Foreword: The Way to Carnegie” (2012) 32:2 Boston College

DeGroff, supra note 13 at 252 [footnotes omitted].

Ibid at 263-64.

Supra note 4.

Peggy Cooper Davis et al, “Making Law Students Healthy, Skillful, and Wise” (2011-2012) 56 NYL Sch L Rev 487 at 488.

Jane H Aiken, “The Clinical Mission of Justice Readiness” (2012) 32:2 Boston College Journal of Law \& Social Justice 231 at 236.

Ibid at 237-38. 
Experiential education is an effective way to explore the normative content of legal education. It is also a mechanism for ensuring legal education remains relevant, responsive, and outwardly focused. This is so for at least two reasons. First, many experiential programs are offered in collaboration with clinics and external groups who are all seeking to deploy law to serve specific purposes for their clients. Seeing first-hand the impact of the lived experience with law, and the contexts in which law falls short, requires students to confront their ideas about justice. Second, experiential learning through community collaboration reinforces the value of legal services. This in turn shines a needed spotlight on concerns about who is able to access those services, and at what cost - and what happens to those who cannot. ${ }^{42}$

I will use as examples the programs I know best, such as the Intensive Program in Aboriginal Lands, Resources \& Governments. The program "began in 1993, after a group of Osgoode students was profoundly affected by the Oka crisis and challenged the [Osgoode Hall] Law School to do something to help Aboriginal people."43 The program has become a centrepiece of experiential education at Osgoode and

combines a rigorous academic experience with challenging placements in the field.

Students from all Canadian law schools are eligible to apply. The full-term program begins with two weeks of intensive training at Osgoode followed by a two-month externship placement. Placements may be close to home or around the world. Past student placements have included: Toronto law firms, Te Awara Fisheries in Rotorua, New Zealand, Treaty Relations Commission of Manitoba, and Upper Skeena Counselling \& Legal Assistance Society (USCLAS) in Hazelton, ... British Columbia. Students are also required to draft a major research paper and make a two-hour presentation to the other participants in the program at the end of term. ${ }^{44}$

The Anti-Discrimination Intensive Program is of more recent origin and represents a collaboration between Osgoode and the Ontario Human Rights Legal Support Centre. ${ }^{45}$ The Centre offers "human rights legal services to individuals throughout Ontario who have experienced discrimination contrary to the Ontario Human Rights Code. The program offers students the opportunity to develop specialized knowledge of anti-discrimination law and to see an administrative law process from beginning to end." ${ }^{46}$ Following an intensive training program at the end of August students undertake a placement at the Centre. Students participate in the Centre's inquiries service, conduct interviews, draft documents, prepare and attend mediations, and partner with a supervising lawyer for hearings before the Human Rights Tribunal.

Stephen Wizner, “Is Social Justice Still Relevant?” (2012) 32:2 Boston College Journal of Law \& Social Justice 345.

“Intensive Program in Aboriginal Lands, Resources \& Governments,” online: Osgoode Hall Law School $<$ http://www.osgoode.yorku.ca/clinics-experiential/clinical-education/aboriginal-lands-resourcesgovernments>.

$44 \quad$ Ibid.

“Anti-Discrimination Intensive Program,” online: Osgoode Hall Law School <http://www.osgoode. yorku.ca/clinics-experiential/clinical-education/anti-discrimination>. Ibid. 
Students also participate in a weekly seminar throughout the program. In the seminar, students develop problem-solving skills, such as how to view disputes from multiple perspectives and how to critically assess and think constructively about prohibitions on discrimination, their impact on society, and the challenges of ensuring access to human rights remedies for diverse and vulnerable communities. Students also complete a research paper which reflects their learning in the seminar and their experience in the placement. The AntiDiscrimination Intensive Program has been singled out as a success in Andrew Pinto's recently issued Report of the Ontario Human Rights Review $2012,{ }^{47}$ and received recognition from the Canadian Race Relations Foundation's Award of Excellence in $2012 .{ }^{48}$ It represents an illustration of the benefits not just of experiential learning but of how such learning dovetails with community engagement and access to justice as well.

Community engagement does not necessarily require external placements. At Osgoode, programs such as the Mediation Intensive Program, the Osgoode Business Clinic, the Innocence Project, and the Community and Legal Aid Services Programme (CLASP) all provide significant opportunities for law student involvement in the community while all are based on campus at Osgoode. ${ }^{49}$

Experiential education also has the potential to blur the boundary between law schools. For example, LawWithoutWalls is an initiative that began at the University of Miami but now includes a wide range of law schools. Students are paired with others from partner institutions to conduct research together on an assigned problem through digital platforms, under the supervision of academic and entrepreneurial mentors. ${ }^{50}$

These examples demonstrate the way in which experiential education can provide an outward orientation to legal education and counter a tendency in many law schools to focus inward. ${ }^{51}$ While it may be too early to assess fully the difference between law students in experiential programs and those in conventional programs, the positive and enduring impact of clinical education on generations of students suggests widespread benefits. One such benefit is exposing students to the dynamic tension inherent in the place of a legal services clinic within a law school. ${ }^{52}$ Students in experiential programs are much more likely to take ownership of their own legal education and to be more engaged in the governance and development of law school programs as a result. An experiential climate empowers law students. Indeed, some of Osgoode's most successful experiential programs emerged directly

Andrew Pinto, Report of the Ontario Human Rights Review 2012 (Toronto: Ontario Ministry of the Attorney General, 2012) at 113-15.

"Osgoode Anti-Discrimination Intensive Program honoured for excellence and innovation” yFile (24 October 2012), online: York University <http://yfile.news.yorku.ca/2012/10/24/osgoode-antidiscrimination-intensive-program-honoured-for-excellence-and-innovation/>.

See generally “Clinical and Intensive Programs at Osgoode,” online: Osgoode Hall Law School <http:// www. osgoode.yorku.ca/clinics-experiential/clinical-education>.

“About LawWithoutWall,” online: LawWithoutWalls <http://www.lawwithoutwalls.org/about>.

The classroom was once seen as a place apart from the community, and architecture only reinforced this sense of isolation. At Osgoode, for example, the classrooms were constructed in the 1960s without windows to the outside world. Students could not see out and community members could not see in. By the 1990s, cutting windows into the brick walls of the classrooms had become a concrete as well as metaphorical priority. By the time the Law School's newly renovated building opened in 2011, every classroom had at least one window.

See Shelley AM Gavigan, “Twenty-Five Years of Dynamic Tension: The Parkdale Community Legal Services Experience” (1997) 35: 3 \& 4 Osgoode Hall LJ 443. 
from student advocacy (for example, the Mediation Intensive Program, established in 2008)..$^{53}$

Whether founded by students or not, experiential programs tend to be more inclusive for students who otherwise might identify as "outsiders" in the law school community. In "Counting Outsiders: A Critical Exploration of Outsider Course Enrollment in Canadian Legal Education," the authors note the importance of clinical pedagogy in connecting law students with the reality of law's implications for vulnerable groups. ${ }^{54}$ The authors observe: "The ability of students to distance themselves altogether from the reality and effects of their work with outsider clients is disrupted when the experiences of those groups with the law becomes a focus of students' legal education." 55

To sum up, experiential education is more likely to produce law students who are:

- $\quad$ focused on creative problem-solving through law

- $\quad$ collaborative and exposed to partnerships

- $\quad$ engaged in access to justice and community development

- $\quad$ motivated to take a more active role in the learning process

- $\quad$ valued and recognized for who they are and what they contribute

- $\quad$ curious about law's contexts, implications, and the lived experience with the justice system(s).

Just as experiential education has an impact on law school curricula, pedagogy, and the law student experience, it also calls into question the relationship between legal education and legal practice. This is the subject of the following section of the discussion.

\section{EXPERIENCING THE FUTURE OF LEGAL EDUCATION}

Future trends suggest a focus on cross-collaboration with a wide range of institutions, and various innovations in teaching that embrace an era of globalization and digitization. Some schools have begun this movement by digitizing the classroom (for example, Harvard's use of blogs, Facebook, clickers, and podcasts).$^{56}$ Others have embraced the global classroom, facilitated through the use of virtual externships and simulations, which focus on practicebased active problem-solving. ${ }^{57}$ The movement of experiential learning pedagogy towards the digital domain has also included projects testing the use of mobile devices and gaming frameworks in legal teaching. Meanwhile, projects such as iLEGALL (iPads and Legal

"Mediation Intensive Program,” online: Osgoode Hall Law School <http://www.osgoode.yorku.ca/ clinics-experiential/clinical-education/mediation-intensive-program>.

Natasha Bakht et al, "Counting Outsiders: A Critical Exploration of Outsider Course Enrollment in Canadian Legal Education” (2007) 45:4 Osgoode Hall LJ 667 at 727-29.

Ibid at 675 .

See "HLS Faculty Digital Teaching Strategies," online: Harvard Law School <http://learning.law. harvard.edu/digitalteaching/strategies/>.

57 See e.g. "Daniel Webster Scholar Honors Program,” online: University of New Hampshire School of Law < http://law.unh.edu/academics/jd-degree/daniel-webster-scholars>; “"Capstone Experience Example 5,” online: Queensland University of Technology, School of Law <https://wiki.qut.edu.au/display/ capstone/Capstone+experience+example+5>. 
Learning $)^{58}$ are experimenting with the use of simulations and assessments through cloud technologies.

There are many implications of the experiential turn in legal education and several are discussed above. Some focus on problem-solving whereas others place a greater focus on community engagement and access to justice. Some have further suggested experiential education may contribute to law students' overall wellness. ${ }^{59}$ In this section, I examine the evolving relationship between more experiential law school programs and the role of transitional professional education programs in two contexts: the phenomenon of the law school law firm, and the rise of professional/practical legal training courses as augmentations to or replacements of traditional apprenticeship programs such as articling.

\section{A. THE LAW SCHOOL FIRM}

One area where the boundary between legal education and legal practice has been blurred is in the concept of law schools developing in-house law firms. There are many ways for law schools to support the delivery of legal services to those in need, from formal legal aid clinics to pro bono clinics in a variety of legal subject areas. These models may involve full-time faculty, adjunct faculty, staff lawyers, or pro bono lawyers providing supervision of law students in working with or on behalf of clients.

In "The Law School Firm,” Bradley Borden and Robert Rhee go a step further and suggest law schools establish affiliated firms, which would be staffed by faculty and lawyers ${ }^{60}$ They suggest this model will bridge the gap between law school and legal practice, while also providing meaningful access to justice for clients. A law school firm model has been viewed by its enthusiasts as the logical next step flowing from the establishment of the clinical requirements at many schools in the US, and is loosely based on the medical school "teaching hospital" model. In "Law Schools under Siege: The Challenge to Enhance Knowledge, Creativity, and Skill Training,” Robert Reis suggests the law school firm model would ensure students are "practice ready." ${ }^{\prime 61}$ Reis explains that it would be useful as a requirement for a fourth year of law school, where tuition would be covered by earnings and in some cases students could receive a modest income or stipend.

To date, the law school firm concept has been implemented in a variety of different ways at a number of US law schools. Arizona State University (ASU) recently implemented the most ambitious law school firm model, in terms of size and cost. The Alumni Law Group was launched as a full-fledged firm (unlike the more common incubator firms discussed below). Dean Douglas Sylvester heralded the model which features five to seven partners who have a minimum of ten years of experience practicing law, overseeing four to five litigation and transactional practice groups, with five recent ASU College of Law graduates

\footnotetext{
58 Jonathan Bainbridge, Paul Maharg \& Rebecca Mitchell, “iPad and Legal Learning (iLEGALL),” online: Academia.edu <http://www.academia.edu/3030702/iPad_and_Legal_Learning_iLEGALL_>. Davis et al, supra note 39.

Bradley T Borden \& Robert J Rhee, “The Law School Firm” (2011) 63:1 SCL Rev 1.

Robert I Reis, "Law Schools under Siege: The Challenge to Enhance Knowledge, Creativity, and Skill Training” (2012) 38:3 Ohio NUL Rev 855.
} 
serving as associates in each, for terms of up to three years. ${ }^{62}$ A total of 30 associates will therefore be retained at any one time. The graduates would be paid for the services provided, while providing such services for a relatively low cost to the people of Pheonix. ASU has partnered with various institutions (for example, the ASU Scottsdale Innovation Center) to gather a client base. It also aims to reach out to the Hispanic and veteran communities, and contemplates charging a lower rate of \$125 per hour. The Alumni Group webpage indicates that:

ASU boasts more practical experiences, through clinics, externships, and pro bono opportunities, than almost any other law school in the country, with individual graduates averaging 250 hours of client contact while in school and each graduating class providing more than 100,000 hours of free legal services. ${ }^{63}$

Pace Law School has established a firm based more on an incubation model, which features legal residencies for recent J.D. graduates under the supervision of practicing attorneys. ${ }^{64}$ The law school firm represents local clients in areas such as immigration, family, employment, and housing law. Clients are charged based on their income and ability to pay for services. As the article indicates, the firm assisted approximately 250 people during its first year of operation. Of those assisted, 100 have the fellows on retainer. City University of New York (CUNY) School of Law's Incubator for Justice has adopted a similar approach. ${ }^{65}$ CUNY attracted lawyers with experience who were looking to transition into solo practices. The Incubator launched in 2007 and since then has trained eight lawyers every 18-month term. While the lawyers are not paid by the school (and must rent an office), they do receive access to school resources and training and other in-kind resources. This program has set the stage for similar models, such as Northeastern University School of Law's Justice Bridge where incubator attorneys, who would later form their own small or solo firms, would be trained in practice management (with program applicants required to submit business plans). ${ }^{66}$

\section{B. Practical/Professional Legal Training Courses}

While the law school firm has yet to gain traction at a Canadian law school, the debate over the role of the law school in transitional professional education on this side of the border has been active and far-reaching (at least in Ontario). Much ink has been spilled in Ontario

"College of Law to launch teaching law firm in summer" ASU News (7 March 2013), online: Arizona State University <https://asunews.asu.edu/20130307_lawteachingfirm>; Delece Smith-Barrow “Consider Law Schools With In-House Firms, Incubators,” US News \& World Report (17 June 2013), online: US News \& World Report <http://www.usnews.com/education/best-graduate-schools/top-lawschools/articles/2013/06/17/consider-law-schools-with-in-house-firms-incubators>.

63 "College of Law to launch teaching law firm in Summer 2013," College of Law News (6 March 2013), online: Arizona State University <http://www.law.asu.edu/News/CollegeofLawNews/TabId/803/Art MID/7835/ArticleID/4416>.

64 See the description of this model in Tania Karas, "Pace Graduates Sign Up for 'Low Bono' Counseling Model” New York Law Journal (9 April 2013), online: New York Law Journal <http://www.newyork lawjournal.com/id=1202595267004\&thepage $=1>$.

65 Jonathan D Glater, "Lawyers Learn How to Be Businesslike” The New York Times (9 January 2008), online: The New York Times <http://www.nytimes.com/2008/01/09/nyregion/09law.html?_r=0>.

66 "The Northeastern University Justice Bridge," online: Hungry Hungry Lawyers < http://hungryhungry lawyers.com/wp-content/uploads/2013/06/Justice-Bridge-Brochure-6-2.pdf > . 
on the "crisis" in articling. ${ }^{67}$ Articling has lacked any formal, consistent instruction so it has always been difficult to evaluate its success as an educational model. At best, articling has succeeded through a mix of mentorship, supervision, learning-by-doing, continuing legal education and constructive feedback, and the lack of any consensus of what an alternative model might look like. Indeed, it is telling that in Ontario, the articling “crisis” has been framed in terms of the gap between candidates seeking articling and available positions, not the quality of the positions or the educational benefits of articling. ${ }^{68}$

Led by the United Kingdom and Australia, Practical or Professional Legal Training Courses (PLTCs) have established both a new domain for legal education and new spheres of innovation. Indeed, beyond PLTCs, lifelong learning in law is fast replacing the notion that legal education ends after licensure.

Much of the literature on PLTCs and its role of bridging the gap between legal education and practice are documented in blog discussions, reform and review proposals, and conference materials from the UK and Australia. Some of these initiatives have been led by law schools (for example, Australia National University's Graduate Diploma in Legal Practice), ${ }^{69}$ while others have been led by private entities (both for profit and non-profit) such as the University of $\mathrm{Law}^{70}$ and College of Law. ${ }^{71}$

The rise of PLTCs in Australia came as a result of the recommendations documented in the 2006 Campbell Report. The report indicated that there existed "no mechanisms to guarantee minimum standards and content of training." "2 The Victorian government adopted the recommendation to replace articled clerkships, albeit with two pathways: Practical Legal Training or Supervised Workplace Training (SWT looks somewhat like articles but involves an approved training plan and the requirement to outsource training for Trust and Office Accounting, and Professional Responsibility). ${ }^{73}$ Law firms adopting the SWT pathway must

Articling has been the subject of two recent task forces in Ontario: see Licensing \& Accreditation Task Force, Report to Convocation, September 25, 2008 (The Law Society of Upper Canada, 2008), online: The Law Society of Upper Canada <http://www.lsuc.on.ca/media/convsep08_licensing.pdf>; Articling Task Force, Final Report, October 25, 2012: Pathways to the Profession: A Roadmap for the Reform of Lawyer Licensing in Ontario (The Law Society of Upper Canada, 2012), online: The Law Society of Upper Canada <http://lsuc.on.ca/WorkArea/DownloadAsset.aspx?id= 2147489848>.

This dynamic is by no means new. Previous calls for abolishing articling also accompanied widening gaps between those seeking articles and those hiring articling students. There were five different special task forces on articling struck by the law society in Ontario between the 1970s and the current "crisis." For a helpful review, see the submission from The Advocates' Society to the Law Society of Upper Canada (29 March 2012), online: Law Society of Uppper Canada <http://www.lsuc.on.ca/Work Area/DownloadAsset.aspx?id=2147 487582>.

69 “Graduate Diploma in Legal Practice,” online: Australian National University <http://law.anu.edu.au/ legalworkshop/gdlp>.

70 "History and heritage," online: The University of Law <http://www.law.ac.uk/about/history-andheritage/ $>$.

“The College of Law," online: The College of Law <http://www.collaw.edu.au/>.

Susan Campbell, Review of Legal Education Report - Pre-Admission and Continuing Legal Education (Melbourne: Victoria Department of Justice, 2006) cited in Kristoffer Greaves, "Support for Law Graduates undertaking Practical Legal Training?,” online: PleagleTrainer Blog <http://thekglawyerblog. com/ptblog/articles/support-for-law-graduates-undertaking-practical-legal-training/\#_ftnref3> (“[i]n Australia in 2006, the Victoria Department of Justice commissioned a Review of Legal Education Services at the direction of the then Attorney General, Hon Rob Hulls MP in 2006. The consultation and review process commenced in March and completed in July 2006. Ms. Susan Campbell produced the Review of Legal Education Report, which quickly became known as 'The Campbell Report.' The report's first recommendation was that PLT replace articles of clerkship”).

73 See generally “Admission to Practice,” online: Law Institute of Victoria <http://www.liv.asn.au/ForLawyers/Careers-Centre/Admission-to-practice>. 
have their training plan approved by the Council of Legal Education. Anecdotally, not many firms have embraced SWT in comparison to firms that enroll their graduates in a PLTC.

Prior to the Campbell Report, the State of Victoria in Australia had already established the Leo Cussen Centre for Law (which received funding from the Legal Services Board and was created by an Act of Parliament in 1972). ${ }^{74}$ The Institute is an independent not-for-profit centre for practical legal training and ongoing professional development that pioneered simulated practice environments as a means to prepare candidates to be lawyers that is alternative to apprenticeship.

Australia has witnessed a number of practical concerns with PLTCs, from unevenness of quality across providers to the difficulty students have balancing PLTCs with full-time or part-time work placements. ${ }^{75}$

In the UK, PLTCs have similarly served as a catalyst for innovation in legal education. In “The Glasgow Graduate School of Law,” Paul Maharg and Elizabeth Li document the way in which the school's practice-oriented diploma program effectively bridges the gap between the LL.B. and the hands-on traineeship that students must undergo upon completion of the diploma. ${ }^{76}$ The program deploys simulations to teach legal skills, and flipped classroom approaches to ensure students obtain a grounding in the necessary substantive areas of law through webcasts and interactive online supervision.

Maharg has also been involved in the Legal Education and Training Review (LETR) research phase, which was "designed to ensure that England and Wales has a system of legal services education and training (LSET) that is fit for the future."77 The LETR report presents a number of recommendations focused on building stronger learning outcomes, course content, advocacy training, structures for supervision, and so on.

With innovation has come growing attention to the structure of legal education, and the division of labour between undergraduate legal education, PLTCs, and bar admission exams and courses. At a UK Learning in Law Conference in 2011, Ruth Deech, Derek Wood, John Carrier, and Valerie Shrimplin presented a paper entitled "From law undergraduate to professional practice," which discussed "the need for widening access to law courses and the Bar, making scholarships available, and ensuring wide representation, whilst maintaining standards, in the current financial climate."78 The authors advocated incorporating ethics

74 “About Leo Cussen Centre for Law,” online: Leo Cussen Centre for Law <http://www.leocussen. vic.edu.au/cb_pages/aboutus.php>.

For discussion, see Kristoffer Greave’s reflections on the 2011 Australasian Professional Legal Education Council Conference at “APLEC 2011,” online: PeagleTrainer Blog <http://thekglawyerblog. com/ptblog/articles/ aplec-2011/>.

76 Paul Maharg \& Elizabeth Li, “The Glasgow Graduate School of Law: A Unique, Simulation-Based Approach to Providing Students with Practical Legal Experience” (Paper delivered at the International Conference on the Future of Legal Education, 21 February 2008), online: Georgia State University $<$ http://law.gsu.edu/FutureOfLegalEducationConference/Papers/Maharg-Li.pdf> at 1.

77 Legal Education and Training Review, Setting Standards: The Future of Legal Services Education and Training Regulation in England and Wales (2013), online: Legal Education and Training Review $<$ http://letr.org.uk/wp-content/uploads/LETR-Report.pdf> at ix.

78 Valerie Shrimplin, “Session report: From law undergraduate to professional practice,” online: UK Centre for Legal Education <http://ukcle.ac.uk/files/downloads/862/2368.05ff5980.Vshrimplin_formatted. doc>. 
teaching throughout a law degree through practical, hands-on case studies, introducing skills and on-the-job training into undergraduate law programs, and mooted the idea of merging the PLTC and Bar Professional Training Course in the UK.

The relevance of the rise of PLTCs in the UK and Australia for Canadian legal education remains to be fully explored. While British Columbia's PLTC involves ten weeks of "practice, procedure and skills" courses, including ethics and professionalism ${ }^{79}$ and most other law societies provide some variation of a bar admission course between articling and licensure, it is fair to say that Ontario's Law Practice Program (LPP) as an alternative to articling will represent Canada's most ambitious foray into the PLTC sphere. The Law Society of Upper Canada adopted a third party model to deliver the LPP, which will include a four-month component of substantive legal training, followed by a four-month work placement. Ryerson University was selected to deliver the LLP (with the University of Ottawa providing a French version of the program), which will welcome its first cohort in September $2014 .^{80}$ There are many questions to be addressed in the development of the LPP, from the financing of the program to its evaluation, but among the most significant ambiguities are the implications of the LPP for law schools. ${ }^{81}$

If law schools are indeed becoming more experiential, as discussed above, the need for professional legal training of the kind envisioned by the LPP may be uncertain. While the UK and Australia law schools are, for the most part, direct entry, Canadian law students have already completed undergraduate studies (and many have also completed graduate studies) before attending law school. Moreover, as tuition and student debt increase, the pressure to reduce the amount of time and resources which must be invested by graduates before they can be licensed to practice is growing. The ferment in US legal education as to whether law schools should offer two-year J.D. programs reflects this dynamic and may be a harbinger of future debates in Canada. ${ }^{82}$

Lakehead University's new law school is organized along a model intended to integrate practical legal training, including a co-op program with local law offices, and has received approval from the Law Society of Upper Canada as satisfying the requirements of an LPP. ${ }^{83}$ Most Canadian law schools offer clinical opportunities to at least a portion of their students, which would appear to accomplish similar goals as the work placement portion of the LPP. While the LPP may be developed as a distinct program from its originating iteration, over time, students may well ask why it is not possible to complete some or all of the components

“Professional Legal Training Course (PLTC),” online: The Law Society of British Columbia <http:// www.lawsociety.bc.ca/page.cfm?cid=31>.

See "Law Practice Program,” online: Ryerson University <http://www.ryerson.ca/llp/>.

Lorne Sossin, "Moving Forward? The Brave New World of the LPP” Dean Sossin's Blog (13 January 2013), online: Osgoode Hall Law School <http://deansblog.osgoode.yorku.ca/2013/01/moving-forwardthe-brave-new-world-of-the-lpp/>. See also Lorne Sossin, “Osgoode's Approach to the 'Integrated' Law School LLP" Dean Sossin's Blog (4 April 2014), online: Osgoode Hall Law School <http:// deansblog.osgoode.yorku.ca/2014/04/osgoodes-approach-to-the-integrated-law-school-llpp/>.

The two-year option has been actively debated in the US but was given unexpected support from President Obama in an off-the-cuff remark in August 2013; see Colleen Flaherty, "2 Years for Law School?” (26 August 2013), online: Inside Higher Ed <http://www.insidehighered.com/news/2013/ 08/26/president-obama-calls-cutting-year-law-school $>$.

“The Curriculum,” online: Lakehead University < https://www.lakeheadu.ca/academics/departments/ law/curriculum>; Heather Gardiner, "LSUC taps Ryerson, U of O for law practice program,” Canadian Lawyer Magazine (21 November 2013), online: Canadian Lawyer Magazine <http://www.canadian lawyermag.com/legalfeeds/1800/lsuc-taps-ryerson-u-of-o-for-law-practice-program.html>. 
of the LPP while at law school. Indeed, this scenario was discussed in the Articling Task Force Minority Report that advocated for simply abolishing articling and encouraging the experiential trend within law schools. ${ }^{84}$

However the relationship between PLTCs and Canadian law schools is resolved: the PLTCs provide an important counterpoint to experiential education within law schools. While the goal of PLTCs is to prepare candidates for legal practice, the goal of experiential education in law school is to facilitate students gaining the most effective and meaningful understanding of legal concepts in context. ${ }^{85}$ While it is open to regulators to value experiential education in law schools, and for many it is valuable precisely because it reflects better preparation for practice than its alternatives, it is vital, in my view, not to lose sight of the distinctly different goals to which regulation and legal education each aim.

While the goals may differ, ideas on experiential pedagogy from PLTCs may well enhance experiential education in law school (and vice versa). For example, the use of "SIMPLE" (SIMulated Professional Learning Environment) which was pioneered in PLTC settings in Scotland and Australia, is now being implemented as part of the University of New Hampshire's revamped upper-year curriculum. ${ }^{86}$

Through innovations such as PLTCs or incubating law firms within law schools, together with existing legal aid clinics within law schools and new forms of collaboration on intensive programs, simulated classes, and externships, the sharp distinctions between legal education and legal practice are breaking down and, in my view, will continue to erode in the future. In other words, while the mission and mandate of law schools remains clear, it is as likely that the mission and mandate will be executed online or on-site in collaboration with a law firm, non-governmental organization, government office, or clinic as in a law school classroom.

\section{Conclusions}

In this brief article, I have discussed the experiential shift in legal education and why I believe this is a welcome development in the context of Canadian legal education. I have also canvassed the implications of this shift, including the growing emphasis on problem-solving curricula, collaborative skills, access to justice, and community engagement. I also have explored the destabilizing implications of this shift for traditional distinctions between legal education in law schools and education for legal practice.

Experiential education is not a panacea. Like any other approach to legal education, it can be done well or poorly. Experiential education does, however, point the way forward to a

$84 \quad$ Supra note 67 at 95.

85 For an interesting comparative analysis of legal learning outcomes in clinical legal education, see Gemma Smyth \& Maggie Liddle, "Lulling Ourselves into a False Sense of Competence: Learning Outcomes and Clinical Legal Education in Canada, the United States and Australia” (2012) 6 CLEAR 15.

86 Karen Barton, John Garvey \& Paul Maharg, "Standardized Clients and SIMPLE (SIMulated Professional Learning Environment): learning professionalism through simulated practice” (Presentation delivered at FutureEd Conference 3, New York Law School, New York, 15 April 2011), online: Northumbria Research Link < http://nrl.northumbria.ac.uk/9954/1/FutureEd_slides\%252C_NY\%252C_ v.2.pdf $>$. 
distinctly engaging, relevant, and collaborative model of learning that is well-suited both to advancing the enduring missions of law schools and to thriving in the midst of an uncertain future. For all of these reasons, the future of legal education may be brighter than we think. 